\title{
Pseudohyponatremia and falsely increased serum osmolal gap caused by paraprotein in a patient with severe metabolic acidosis - a case study
}

\author{
Tomáš Š́lek*
}

Clinical Biochemistry and Pharmacology, Tomas Bata Hospital, Czech Republic Biomedical Sciences, University of Ostrava, Faculty of Medicine, Czech Republic

\begin{abstract}
Introduction: The aim of the study is to present a case study of a 63-year-old male with pseudohyponatremia, falsely increased serum osmolal gap and severe metabolic acidosis. Material and Methods: Venous whole blood (direct sodium selective electrode measurement) and serum (indirect sodium selective electrode measurement) were used to measure sodium concentration. Serum cholesterol, triacylglycerides and total protein were measured to confirm pseudohyponatremia. Base excess in extracellular fluid and serum bicarbonate concentrations were employed as markers of metabolic acidosis. Serum protein electrophoresis and free light chain analysis were used for the detection of paraproteins. Results: Venous whole blood acid base analysis showed a pH of 7.171, negative base excess in extracellular fluid of - $18.6 \mathrm{mmol} / \mathrm{L}$ and sodium concentration of $140 \mathrm{mmol} / \mathrm{L}$. Serum test measurement revealed serum sodium concentration of $130 \mathrm{mmol} / \mathrm{L}$, osmolal gap of $24 \mathrm{mmol} / \mathrm{kg}$, creatinine concentration of $702 \mu \mathrm{mol} / \mathrm{L}$, HCO3- concentration of $6.1 \mathrm{mmol} / \mathrm{L}$ and total protein concentration of $134.9 \mathrm{~g} / \mathrm{L}$. Serum paraprotein IgG kappa with a concentration of $86 \mathrm{~g} / \mathrm{L}$ and a serum free light chains kappa/lambda ratio of 223.5, along with the final diagnosis of multiple myeloma were detected. Toxic alcohol ingestion was considered, both methanol and ethylene glycol tests were negative. Conclusions: High paraprotein concentrations in serum may lead to pseudohyponatremia when measured by indirect ion selective electrodes. Multiple myeloma frequently leads to renal failure with metabolic acidosis.
\end{abstract}

Keywords: pseudohyponatremia, hyponatremia, acidosis, paraproteins, multiple myeloma Received: 15 ${ }^{\text {th }}$ March 2021; Accepted: $6^{\text {th }}$ April 2021; Published: $8^{\text {th }}$ April 2021

\footnotetext{
* Corresponding author: Tomáš Šálek, Clinical Biochemistry and Pharmacology, Tomas Bata Hospital, Havlíčkovo nábřeží, 76275, Zlín, Czech Republic. E-mail: tsalek@seznam.cz
} 


\section{Introduction}

The differential diagnosis of severe metabolic acidosis in the emergency department is broad and heterogeneous, it includes mainly hypoxia states, renal failure, sepsis, drug induced metabolic acidosis and, rarely, toxic alcohol poisoning (1). The serum osmolal gap (OG) is a useful parameter for the detection of toxic alcohol poisoning. The $\mathrm{OG}$ is calculated according to the following equation:

\section{OG = measured serum osmolality - calculat- ed serum osmolality}

Serum calculated osmolality (OSMcalc) is derived from serum sodium, glucose and urea concentrations using the following equation:

OSMcalc $=2 *$ sodium $(\mathrm{mmol} / \mathrm{L})+$ glucose $(\mathrm{mmol} / \mathrm{L})+$ urea $(\mathrm{mmol} / \mathrm{L})(2)$.

If serum OG is higher than $10 \mathrm{mmol} / \mathrm{kg}$ the presence of an alcohol is possible (3).

The aim of this case study is to present a patient with severe metabolic acidosis and a falsely increased serum OG.

The local hospital Ethic committee approved the publication (approval number 2021-20).

The patient signed an informed consent regarding the publication of his case study.

\section{Case report}

A 63-year old male was presented to the Emergency department with lower back pain lasting for two weeks. He received non-steroid anti-inflammatory drugs from his general practitioner without effect. The medical history included hypertension and benign prostate hyperplasia. He had an inguinal hernia surgery in 2012. The medication included $10 \mathrm{mg}$ perindopril and 10 mg amlodipine daily. He was without allergies. The venous whole blood acid base analysis measured by direct ion selective electrodes in the Emergency department showed severe metabolic acidosis, respiratory alkalosis, low hemoglobin level, and increased potassium, chloride and ionized calcium concentrations (Table1).

The serum biochemical tests revealed a newly diagnosed renal failure, decreased sodium concentration (measured by indirect sodium selective electrode), low serum bicarbonate concentration, serum OG of $24 \mathrm{mmol} / \mathrm{kg}$, ethanol concentration below the limit for quantification and hypoalbuminemia. The lower serum concentrations of both potassium (pseudonormokalemia) and chloride compared to whole blood are also visible (Table 2).

Different sodium concentrations were found in serum and whole venous blood. New sample collections were obtained and the results con-

Table 1. Venous whole blood acid base analysis tests

\begin{tabular}{lccc}
\hline Whole blood test & Result & Unit & Reference range \\
\hline Glucose & 4.5 & $\mathrm{mmol} / \mathrm{L}$ & $3.9-5.5$ \\
\hline Sodium & 140 & $\mathrm{mmol} / \mathrm{L}$ & $136-144$ \\
\hline Potassium & 5.6 & $\mathrm{mmol} / \mathrm{L}$ & $3.5-4.8$ \\
\hline Chloride & 123 & $\mathrm{mmol} / \mathrm{L}$ & $95-107$ \\
\hline Calcium (ionized) & 1.49 & $\mathrm{mmol} / \mathrm{L}$ & $1.15-1.29$ \\
\hline $\mathrm{pH}\left(37^{\circ} \mathrm{C}\right)$ & 7.171 & $\mathrm{pH} \mathrm{units}$ & $7.36-7.44$ \\
\hline $\mathrm{pCO}\left(37^{\circ} \mathrm{C}\right)$ & 3.17 & $\mathrm{kPa}$ & $4.8-5.8$ \\
\hline Base excess in extracellular fluid & -18.6 & $\mathrm{mmol} / \mathrm{L}$ & $-2.5-+2.5$ \\
\hline Hemoglobin & 70 & $\mathrm{~g} / \mathrm{L}$ & $135-175$ \\
\hline Lactate & 0.7 & $\mathrm{mmol} / \mathrm{L}$ & $0.2-2.0$ \\
\hline
\end{tabular}


firmed decreased serum sodium concentration and normal whole blood sodium concentration. Increased serum total protein concentration of $133.4 \mathrm{~g} / \mathrm{L}$ was detected in the next serum sample while paraprotein IgG kappa with the concentration of $86 \mathrm{~g} / \mathrm{L}$ was detected later. Serum free light chain analysis showed a markedly in- creased kappa/lambda ratio. The results of serum proteins are shown in Table 3.

Urine immunofixation electrophoresis showed the monoclonal kappa chains (Bence Jones protein) concentration of $0.106 \mathrm{~g} / \mathrm{L}$ and monoclonal the IgG kappa concentration of $0.026 \mathrm{~g} / \mathrm{L}$. Tests for the detection of methanol and ethylene glycol

Table 2. Serum test results (sampling at the same time as acid base analysis tests)

\begin{tabular}{lccc}
\hline Serum test & Result & Unit & Reference range \\
\hline Glucose & 6.2 & $\mathrm{mmol} / \mathrm{L}$ & $3.9-5.5$ \\
\hline Sodium & 130 & $\mathrm{mmol} / \mathrm{L}$ & $136-144$ \\
\hline Potassium & 5.1 & $\mathrm{mmol} / \mathrm{L}$ & $3.8-5.1$ \\
\hline Chloride & 116 & $\mathrm{mmol} / \mathrm{L}$ & $95-107$ \\
\hline Ethanol & $<0.1$ & $\mathrm{promille}$ & $<0.1$ \\
\hline Osmolality measured & 331 & $\mathrm{mmol} / \mathrm{kg}$ & $275-295$ \\
\hline Osmolality calculated & 307 & $\mathrm{mmol} / \mathrm{kg}$ & - \\
\hline Calculated osmolal gap & 24 & $\mathrm{mmol} / \mathrm{kg}$ & $0-10$ \\
\hline Urea & 41 & $\mathrm{mmol} / \mathrm{L}$ & $3.0-8.0$ \\
\hline Creatinine & 702 & $\mu \mathrm{mol} / \mathrm{L}$ & $64-104$ \\
\hline Uric acid & 731 & $\mathrm{mmol} / \mathrm{L}$ & $140-360$ \\
\hline HCO ${ }^{-}$ & 6.1 & $\mathrm{mmol} / \mathrm{L}$ & $22-29$ \\
\hline Total bilirubin & 3 & $\mu \mathrm{mol} / \mathrm{L}$ & $<20$ \\
\hline Alanine aminotransferase & 10.2 & $\mathrm{U} / \mathrm{L} 37^{\circ} \mathrm{C}$ & $<43.8$ \\
\hline Aspartate aminotransferase & 11.4 & $\mathrm{U} / \mathrm{L} \mathrm{37}{ }^{\circ} \mathrm{C}$ & $<40.2$ \\
\hline Gamma-glutamyl transferase & 45.6 & $\mathrm{U} / \mathrm{L} \mathrm{37}{ }^{\circ} \mathrm{C}$ & $<106.2$ \\
\hline Alkaline phosphatase & 109.9 & $\mathrm{U} / \mathrm{L} \mathrm{37}{ }^{\circ} \mathrm{C}$ & $<150$ \\
\hline Cholesterol total & 2.53 & $\mathrm{mmol} / \mathrm{L}$ & $<5.0$ \\
\hline Triacylglycerides & 1.81 & $\mathrm{mmol} / \mathrm{L}$ & $<1.7$ \\
\hline Albumin & 32.3 & $\mathrm{~g} / \mathrm{L}$ & $36.0-45.0$ \\
\hline C-reactive protein & 8.0 & $\mathrm{mg} / \mathrm{L}$ & $<2.0$ \\
\hline
\end{tabular}

Table 3 Serum proteins and calcium test results

\begin{tabular}{lccc}
\hline Serum test & Result & Unit & Reference range \\
\hline Total protein & 134.9 & $\mathrm{~g} / \mathrm{L}$ & $64.0-79.0$ \\
\hline Albumin & 29.4 & $\mathrm{~g} / \mathrm{L}$ & $36.0-45.0$ \\
\hline Free kappa & 1788 & $\mathrm{mg} / \mathrm{L}$ & $3.3-19.4$ \\
\hline Free lambda & 8 & $\mathrm{mg} / \mathrm{L}$ & $5.7-26.3$ \\
\hline Free kappa/free lambda ratio & 223.5 & - & $0.26-1.65$ \\
\hline Paraprotein concentration by serum protein electrophoresis & 86 & $\mathrm{~g} / \mathrm{L}$ & $0-0$ \\
\hline Type of paraprotein by Immunofixation electrophoresis & IgG kappa & - & - \\
\hline Beta-2-micriglobulin & 22.28 & $\mathrm{mg} / \mathrm{L}$ & $<2.64$ \\
\hline Calcium & 2.20 & $\mathrm{mmol} / \mathrm{L}$ & $2.15-2.55$ \\
\hline Calcium corrected for 40 g of albumin & 2.41 & $\mathrm{mmol} / \mathrm{L}$ & $2.15-2.55$ \\
\hline
\end{tabular}


concentrations were negative. A complete blood count revealed a white blood cell count of $8.9 \mathrm{x}$ $10^{9} / \mathrm{L}$ and a thrombocyte count of $165 \times 10^{9} / \mathrm{L}$. The final diagnosis was multiple myeloma. High concentrations of paraprotein have likely interfered with the serum sodium concentration measurement and affected the serum OG calculation.

\section{Discussion}

We presented the case study of pseudohyponatremia and false positive serum osmolal gap due to the presence of a large quantity of paraprotein. Liamis et al reported that pseudohyponatremia can be caused by hyperproteinemia or hyperlipidemia when serum sodium concentration is measured by indirect sodium selective electrodes. Direct ion selective electrodes are not prone to indicating pseudohyponatremia (4). Our patient had marked serum hyperproteinemia and indirect ion selective electrode serum sodium measurement in the hospital's central laboratory led to pseudohyponatremia. Lower serum concentrations of both potassium and chloride compared to whole blood are also visible.

$\mathrm{Yu}$ et al found pseudohyponatremia and falsely increased osmolal gap in a patient with multiple myeloma (5). We found similar results in our case study.

Nikolac reported that accumulation of lipoprotein particles in the blood sample affects measurement of serum electrolytes by the volume displacement effect. Flame photometry and indirect potentiometry measure electrolyte concentrations in the total plasma volume, including the lipid phase (6). Serum lipids were not markedly increased in this case study.

Ghersin et al showed that the lysis of high number of fragile white blood cells in patients with T-cell acute lymphoblastic leukemia causes pseudohyponatremia (7). Our patient had normal white blood cell count.
Quiñones-Torrelo evaluated serum of 18278 patients and diagnosed eight cases of monoclonal gammopathies in patients with suspected interferences of serum conjugated bilirubin and uric acid measurement (8). It shows that paraprotein interferences are relatively frequent.

Raphael reported that chronic kidney disease is commonly accompanied by metabolic acidosis (9). Our patient presented to the Emergency department with renal failure but it was not clear if metabolic acidosis could be completely attributed to renal failure. Neither methanol nor ethylene glycol were detected.

Śálek demonstrated a case study of a patient with pseudohyperkalemia and concluded that pseudohyperkalemia should be always excluded before implementing treatment (10). Similar approach should also be chosen in patients with pseudohyponatremia.

The limitation of this study is the fact that we did not perform arterial blood gas analysis that is the test of choice for blood gas analysis. But venous whole blood gas testing is also acceptable (11).

\section{Conclusion}

The presence of paraprotein in blood can cause analytical interferences in laboratory testing. Both laboratory experts and clinical professionals should be aware of it. This case study demonstrated serum pseudohyponatremia and falsely increased osmolal gap due to the presence of a large quantity of paraprotein.

\section{Abbreviations \\ OG - osmolal gap \\ OSMcalc - serum calculated osmolality}

\section{Authors' contributions}

TŠ; writing the article, data collection, interpretation of results, final approval, accountable of all aspects of work 


\section{Conflict of interest}

\section{Author declare no conflict of interest}

\section{References}

1. Matyukhin I, Patschan S, Ritter O, Patschan D. Etiology and Management of Acute Metabolic Acidosis: An Update. Kidney Blood Press Res. 2020;45(4):523-31. DOI: 10.1159/000507813

2. Choy KW, Wijeratne N, Lu ZX, Doery JC. Harmonisation of Osmolal Gap - Can We Use a Common Formula? Clin Biochem Rev. 2016;37(3):113-9.

3. Jung B, Martinez M, Claessens YE, Darmon M, Klouche K, Lautrette A, et al; Société de Réanimation de Langue Française (SRLF); Société Française de Médecine d'Urgence (SFMU). Diagnosis and management of metabolic acidosis: guidelines from a French expert panel. Ann Intensive Care. 2019 Aug 15;9(1):92. DOI: 10.1186/s13613-019-0563-2

4. Liamis G, Liberopoulos E, Barkas F, Elisaf M. Spurious Electrolyte Disorders: A Diagnostic Challenge for Clinicians. Am J Nephrol. 2013;38(1):50-7. DOI: 10.1159/000351804

5. Yu Z, Parker KM, Blick KE. Markedly Decreased Serum Sodium Concentration in a Patient With Multiple Myeloma. Lab Med. 2005;36(4):224-6. DOI: 10.1309/

\section{MB2J65E60L139LPG}

6. Nikolac N. Lipemia: causes, interference mechanisms, detection and management. Biochem Med (Zagreb). 2014;24(1):57-67. DOI: 10.11613/BM.2014.008

7. Ghersin Z, Fernandes ND, Winkler A, Yager P. Pseudohyperkalemia and Pseudohyponatremia in Two Children with T-Cell Acute Lymphoblastic Leukemia. J Pediatr [Internet]. 2021 Jan 22:S0022-3476(21)00078-0. DOI: 10.1016/j.jpeds.2021.01.044

8. Qui-ones-Torrelo C, Villanueva-Gil MP, Rodríguez-Mu-oz A, Abellán-Tejada L, Aparici-Ibá-ez M, Carratalá-Calvo A. When an Analytical Interference Is a Useful Diagnostic Tool: Finding Monoclonal Gammopathies in Routine Analysis. J Clin Lab Anal. 2016 Mar;30(2):140-4. DOI: 10.1002/jcla.21827

9. Raphael KL. Metabolic Acidosis and Subclinical Metabolic Acidosis in CKD. J Am Soc Nephrol. 2018;29(2):376-82. DOI: 10.1681/ASN.2017040422

10. Š́lek T. Pseudohyperkalemia - Potassium released from cells due to clotting and centrifugation - a case report. Biochem Med (Zagreb). 2018;28(1):011002. DOI: 10.11613/BM.2018.011002

11. McKeever TM, Hearson G, Housley G, Reynolds C, Kinnear W, Harrison TW, et al. Using venous blood gas analysis in the assessment of COPD exacerbations: a prospective cohort study. Thorax. 2016;71(3):210-5. DOI: 10.1136/thoraxjnl-2015-207573 